\title{
Nutritional and technological properties of a quinoa (Chenopodium quinoa Willd.) spray-dried powdered extract
}

\author{
Nelson Romano ${ }^{\mathrm{a}}$, María Micaela Ureta ${ }^{\mathrm{a}}$, María Guerrero-Sánchez ${ }^{\mathrm{b}}$, Andrea Gómez-Zavaglia ${ }^{\mathrm{a}, *}$ \\ a Center for Research and Development in Food Cryotechnology (CCT-Conicet La Plata, UNLP), RA-1900, Argentina \\ ${ }^{\mathrm{b}}$ BiosearchLife, Granada, Spain
}

\section{A R T I C L E I N F O}

\section{Keywords}

Quinoa extract

Spray-drying

Functional components

Starch gelatinization

Ready-to-eat

\begin{abstract}
A B S T R A C T
The relevance of an appropriate nutrition requires innovation in the design of food ingredients. The goal of this work was to obtain a powdered extract of quinoa by using spray-drying. To this aim, quinoa flour was suspended in water to obtain a soluble fraction mainly composed of proteins, starch, fiber, lipids, antioxidants and minerals. The spray-drying conditions of this quinoa soluble fraction were set-up in terms of inlet temperatures (150, 160, 170 and $180{ }^{\circ} \mathrm{C}$ ) and feed flow $(4.5,7.5,10.5 \mathrm{~mL} / \mathrm{min})$. The obtained powders were characterized by determining the proximate composition, antioxidant activity, microstructure, fatty acids' profile, and starch and proteins' structures. A correlation among the drying parameters and the chemical and functional attributes of the powders was addressed using principal component analysis. From a technological viewpoint the use of moderate feed flows $(7.5 \mathrm{~mL} / \mathrm{min})$ and high inlet temperatures $\left(180^{\circ} \mathrm{C}\right)$ was the best combination to obtain high powder yields ( $85 \%$ d.b.), low $\mathrm{a}_{\mathrm{w}}(0.047 \pm 0.005)$ and high solids content $(0.956 \pm 0.005)$. The drying temperature positively affected the structure of starch, improving swelling and favoring moderate agglomeration which increases the encapsulation properties of quinoa. These results support the use of spray-drying as a suitable method to obtain powdered extracts of quinoa without affecting the nutritional value, thus supporting their use as functional ingredients in the formulation of ready-to-eat foods.
\end{abstract}

\section{Introduction}

Quinoa (Chenopodium quinoa Willd.) is a natural food resource, ancestrally cultivated in the Andean region of South-America, resistant to drought and frost (Abugoch, Romero, Tapia, Silva, \& Rivera, 2008). Although the culture of quinoa remained forgotten or marginalized for centuries in favor to other crops (i.e., wheat, rice, corn), its high nutritional value encouraged its increasing revalorization in the last years (Mota et al., 2016). In line with this, the Food and Agriculture Organization of the United Nations (FAO) declared 2013 as the "International Year of Quinoa", in recognition of the practices of the ancestral Andean inhabitants.

Quinoa is considered a pseudo-cereal with very well-documented benefits for human health. These benefits include a high protein content, being one of the few food products from vegetal origin containing the nine essential aminoacids (Mota et al., 2016). Quinoa is also rich in fiber and vitamins from the B group (especially folic acid), and vitamins C and E (Pereira et al., 2019). In addition, it contains calcium, phosphorus, iron, magnesium, potassium, manganese and zinc, and no sodium (Abugoch et al., 2008), together with high concentrations of antioxidants (tocopherols), and unsaturated lipids, mainly represented by linoleic and linolenic acids (Pereira et al., 2019). Furthermore, as it is gluten free, it provides a suitable product for people with celiac disease (Abugoch, 2009).

Because of such nutritional value, diverse attempts have been made to incorporate natural quinoa into elaborated products. Different products containing quinoa (both as whole grain and as flour) have been formulated and are commercially available. Quinoa flour can be obtained by washing (desaponification), drying and grinding the grains (Abugoch et al., 2009). Extractive processes lead to the production of starch hydrolyzates (Srichuwong \& Jane, 2007) and protein isolates (Abugoch et al., 2008), which in turn, can be used to prepare emul-

Abbreviations: FAO, Food and Agriculture Organization of the United Nations; AOAC, Association of Official Analytical Chemists; d.b., dry basis; $\mathrm{a}_{\mathrm{w}}$, water activity; WI, White-

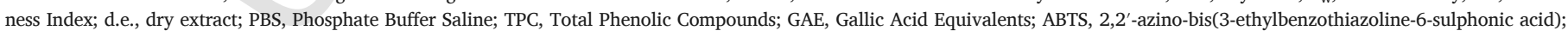

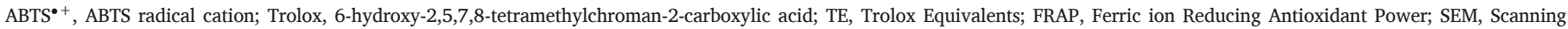

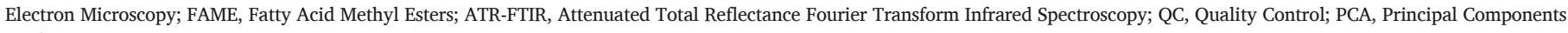
Analysis.

* Corresponding author at: Calle 47 y 116 La Plata, Buenos Aires 1900, Argentina.

E-mail address: angoza@qui.uc.pt (A. Gómez-Zavaglia) 
sions (Gürbüz, Kauntola, Ramos Diaz, Jouppila, \& Heinonen, 2018). Other technological applications of quinoa flour involve gelation, water-holding and foaming capacity (Abugoch et al., 2008). This technological versatility of quinoa supports its excellent capacity to substitute wheat flour in the elaboration of cookies (Jan, Panesar, \& Singh, 2018) and other bakery products (Garcia et al., 2018), gluten-free pasta (Lorenzo, Sosa, \& Califano, 2018), cereal bars (Kaur, Ahluwalia, Sachdev, \& Kaur, 2018), and even its use as milk replacer (Jeske, Zannini, Cronin, \& Arendt, 2018). However, the high content of sensitive compounds (i.e., unsaturated fatty acids, proteins, antioxidants, vitamins, starch) represents a great challenge for technological processes, limiting the stability of the obtained products.

The current consumer is very concerned about the quality and functionality of the food products (Jan et al., 2018). Besides that, the lack of time associated to the modern lifestyle makes difficult the incorporation of fresh products into human diets. Therefore, there is an increasing demand of ready-to eat powdered products, easy to prepare and to ingest, but at the same time, with high nutritional value (Arribas, Cabellos, Cuadrado, Guillamón, \& Pedrosa, 2019). In this context, quinoa appears as a very promising input to fulfill this demand because of its high nutritional value. Therefore, obtaining quinoa powders retaining its nutritional benefits appears as an encouraging way to produce versatile ingredients to be incorporated in a wide range of foods and beverages, thus enhancing their nutritional value.

The elaboration of ready-to-eat food products generally involves dehydration processes. Among the different dehydration processes that can be used at industrial level (i.e., freeze-drying, freezing), the use of spray-drying has systematically increased over the years. The process leads to the transformation of liquid systems (i.e., solutions, dispersions, emulsions) into dry particulate powders when they get in contact with a drying medium (air) at high temperatures (Sosa et al., 2016). Because of the low energy consumption (compared to processes such as freeze-drying), reduced processing times (compared to freeze-drying) and the reduced costs of storage and transportation (compared to freezing), it is an especially useful technology for the cost-effective production of dehydrated food products and ingredients at industrial level (Santivarangkna, Higl, \& Foerst, 2008). Despite all these advantages, using high temperatures may lead to the decrease of the nutritional value of particularly sensitive components, namely proteins, lipids and polyphenols, and also to alterations in flavors, color and solubility (Gharsallaoui, Roudaut, Chambin, Voilley, \& Saurel, 2007).

Considering the economic and strategic importance of ready-to-eat powdered products based on whole quinoa, and the cost-effectiveness of the spray-drying process, the goal of this work was to obtain a soluble powder retaining its nutritional value. To this aim, quinoa flour was suspended in water to obtain a soluble fraction mainly composed of proteins, starch, fiber, lipids, antioxidants and minerals, which was further spray-dried. The spray-drying conditions were set-up in terms of inlet temperatures and feed flow, and the obtained powders were characterized by determining the proximate composition, antioxidant activity, microstructure, fatty acids' profile, and starch and proteins' structures. Finally, the correlation among all the investigated parameters in the different spray-drying conditions was established by means of principal component analysis. The stability of the quinoa spray-dried powdered extracts supports their use as adequate ingredients to be incorporated in ready-to-eat food products.

\section{Materials and methods}

\subsection{Obtaining and characterization of quinoa flour and its soluble fraction}

\subsubsection{Quinoa flour}

Five hundred grams of quinoa grains (Chenopodium quinoa Willd.) white variety obtained from a local market (Cerrillos, Salta, Ar- gentina) were desaponified (soaking with tap water and grinding) and dehydrated in a forced convection oven at $40{ }^{\circ} \mathrm{C}$ for $12 \mathrm{~h}$. After this, the whole grains were milled with a grinder $(700 \mathrm{rpm})$ (Moulinex, Buenos Aires, Argentina) and meshed, to obtain particles with a diameter lower than $500 \mu \mathrm{m}$.

\subsubsection{Soluble fraction of quinoa flour}

Quinoa flour was suspended in distilled water to obtain a concentration of $10 \% \mathrm{w} / \mathrm{v}$. The suspension was incubated at $50{ }^{\circ} \mathrm{C}$ for $2 \mathrm{~h}$, under stirring at $200 \mathrm{rpm}$, and pH 9 [adjusted with $2 \mathrm{~N} \mathrm{NaOH}$ (Anedra, Buenos Aires, Argentina) to increase the solubilization of proteins (Elsohaimy, Refaay, \& Zaytoun, 2015). Then, it was allowed to stand for $30 \mathrm{~min}$ at $25{ }^{\circ} \mathrm{C}$ to enable decantation.

The soluble fraction, containing all the quinoa components but insoluble fiber, was aspersed with a peristaltic pump (Seko group, Italy) (flux: $10 \mathrm{~mL} / \mathrm{min}$ ). The total solids content of the soluble fraction was determined according to the Association of Official Analytical Chemists (AOAC) international methods (Bradley, 2010).

\subsubsection{Proximate composition of the soluble fraction}

Moisture content of the soluble fraction was assessed by determining the weight loss upon drying in a vacuum oven at $45^{\circ} \mathrm{C}$ until constant weight ( $c a .24 \mathrm{~h}$ ). Total nitrogen was assessed using the Kjeldahl method (AOAC, 1995) (conversion factor: 6.25). Lipids were determined by extraction with diethyl ether in a Soxhlet system (AOAC, 1995). Ash content was evaluated by carbonization of the dried samples followed by incineration in a muffle furnace at $550{ }^{\circ} \mathrm{C}$. Dietary fiber was determined using Megazyme testkit K-ACHDF 11/08 (Megazyme International Ireland Limited, Bray, Ireland), according to the manufacturer's procedure. Carbohydrate content was determined by difference. The proximate composition was expressed in grams per $100 \mathrm{~g}$ of dry basis (d.b.). For comparison, all these determinations were also carried out on quinoa flour (Section 2.1.1).

\subsection{Spray-drying soluble fraction of quinoa samples}

The soluble fraction (Section 2.1.2) was homogenized for $10 \mathrm{~min}$ at $20{ }^{\circ} \mathrm{C}$ and $13,500 \mathrm{rpm}$ in an Ultra Turrax T25 high-shear probe mixer (IKA, Staufen im Breisgau, Germany), to eliminate aggregated particles or some remaining insoluble fiber. Then, samples were spray-dried in a laboratory-scale spray-dryer (Büchi B290 mini spray-dryer, Flawil, Switzerland) at constant air inlet temperatures of $150,160,170$ or $180{ }^{\circ} \mathrm{C}$, and $4.5,7.5$ or $10.5 \mathrm{~mL} / \mathrm{min}$ flow rate (Quintana, Gerbino, \& Gómez-Zavaglia, 2018). In all conditions, the pressure in the compressor was 75 psi. The spray-dryer was equilibrated with water before each run. The drying yield was determined as the percentage ratio between the total mass of product recovered and the mass of extract fed to the system (d.b.).

\subsection{Analysis of physical and functional properties of spray-dried soluble fraction of quinoa}

\subsubsection{Water activity $\left(a_{w}\right)$}

The $\mathrm{a}_{\mathrm{w}}$ of spray-dried samples was determined at $25{ }^{\circ} \mathrm{C}$ in an Aqualab 4TE equipment (Meter Group Inc., Pullman WA, United States) with a capacitance sensor (accuracy: $\pm 0.015 \mathrm{a}_{\mathrm{w}}$ ).

\subsubsection{Determination of color}

The CIELab coordinates values $\left(\mathrm{L}^{*}, \mathrm{a}^{*}, \mathrm{~b}^{*}\right)$ of the powders were evaluated by reflectance in a Minolta CR-400 colorimeter Chroma Meter (Konica Minolta Sensing, Inc., Osaka, Japan). The instrument was calibrated with a standard white tile $\left(\mathrm{L}^{*}=94.02, \mathrm{a}^{*}=-0.17, \mathrm{~b}^{*}=2.85\right)$ before measurements. Color was registered randomly at five different spots of each sample. Each value represents the aver- 
age of three determinations. Whiteness index (WI) was calculated according to Eq. (1):

$W I=100-\sqrt{\left(100-L^{*}\right)^{2}+a^{* 2}+b^{* 2}}$

WI represents the overall whiteness of food products that may indicate the extent of discoloration during the drying process (Hsu, Chen, Wenga, \& Tsenga, 2003; Pathare, Opara, \& Al-Julanda Al-Said, 2013).

\subsubsection{Antioxidant activity}

2.3.3.1. Extraction One gram of spray-dried samples (Section 2.2) was suspended for $2 \mathrm{~h}$, in $40 \mathrm{~mL}$ of extraction solvent, consisting in methanol (Sigma-Aldrich, Missouri, USA), $0.16 \mathrm{M}$ hydrochloric acid (Sigma-Aldrich, Missouri, USA), and water (8:1:1 ratio). The extracts were separated by decantation and the residues were extracted with $40 \mathrm{~mL}$ of $70 \% \mathrm{v} / \mathrm{v}$ acetone (Sigma-Aldrich, Missouri, USA), for $2 \mathrm{~h}$. The methanolic extracts were incorporated into the acetonic ones. The mixture was allowed to decant, and then, it was centrifuged at 13,500 rpm and stored at $-20{ }^{\circ} \mathrm{C}$ in darkness (Quintana et al., 2019). All determinations were carried out on the final extracts. All these determinations were also carried out on quinoa flour as controls (Section 2.1.1).

2.3.3.1.1. Total phenolic content (TPC) Total phenolic content was determined according to Kim, Jeong, and Lee (2003). Briefly, $50 \mu \mathrm{L}$ of appropriately diluted extracts were mixed with $50 \mu \mathrm{L}$ of Folin-Ciocalteu reagent, and shaken. After $3 \mathrm{~min}, 100 \mu \mathrm{L}$ of $20 \% \mathrm{w} / \mathrm{v} \mathrm{Na}_{2} \mathrm{CO}_{3}$ (Anedra, Buenos Aires, Argentina) prepared in a $0.1 \mathrm{M} \mathrm{NaOH}$ solution were incorporated. Samples were incubated for $90 \mathrm{~min}$ at $20{ }^{\circ} \mathrm{C}$ under shaking. Then, the absorbance was read at $750 \mathrm{~nm}$. Calibration was carried out using standard solutions of gallic acid (Sigma-Aldrich, Missouri, USA) $(0-18 \mathrm{mg} / \mathrm{L})$. Total phenolic contents were expressed as $\mathrm{mg}$ gallic acid equivalents (GAE) per gram of dry extract (d.e.).

2.3.3.1.2. 2,2'-azino-bis(3-ethylbenzothiazoline-6-sulphonic acid (ABTS) radical cation $\left(\mathrm{ABTS}^{\bullet+}\right)$ scavenging assay The antioxidant activity was evaluated by the method of discoloration of $\mathrm{ABTS}^{\bullet+}$ solution. First, $50 \mathrm{~mL}$ of $2 \mathrm{mM}$ ABTS aqueous solution was reacted with $200 \mu \mathrm{L}$ of $70 \mathrm{mM}$ potassium persulfate solution (Anedra, Buenos Aires, Argentina). This mixture was kept in the dark for at least $16 \mathrm{~h}$ at $25{ }^{\circ} \mathrm{C}$ and was stable in this form for two days (Re et al., 1999).The $\mathrm{ABTS}^{\bullet+}$ solution was diluted in $10 \mathrm{mM}$ phosphate buffered saline solution $\left(\mathrm{K}_{2} \mathrm{HPO}_{4}\right.$ $0.144 \mathrm{~g} / \mathrm{L} ; \mathrm{NaCl} 9.00 \mathrm{~g} / \mathrm{L} ; \mathrm{Na}_{2} \mathrm{HPO}_{4} 0.795 \mathrm{~g} / \mathrm{L}, \mathrm{pH}$ 7.4) (PBS) to an initial absorbance of $0.700 \pm 0.021$ at $734 \mathrm{~nm}$, before use. This solution was freshly prepared for each analysis. For the evaluation of the radical scavenging activity, $40 \mu \mathrm{L}$ of extract solution $(100 \mathrm{mg} / \mathrm{mL}$ in ethanol) was added to $1.96 \mathrm{~mL}$ of $\mathrm{ABTS}^{\bullet+}$ solution. PBS was used as a blank. The decrease of absorbance at $734 \mathrm{~nm}$ (Perkin Elmer UV-vis Lambda 2, Germany) was measured during $6 \mathrm{~min}$. Results were expressed based on the 6-hydroxy-2,5,7,8-tetramethylchroman-2-carboxylic acid (Trolox) calibration curve $(0.5-0.7 \mathrm{mM}$ ) as micromole of Trolox equivalents (TE)/g d.e.

2.3.3.1.3. Ferric ion reducing ability of plasma (FRAP) The FRAP assay was carried out at $37{ }^{\circ} \mathrm{C}$ and $\mathrm{pH} 3.6$, according to Benzie and Strain (1996). A blue colored ferrous-tripyridyl-s-triazine complex (TPTZ) is produced as result of the ferric $\left(\mathrm{Fe}^{3+}\right)$ to ferrous $\left(\mathrm{Fe}^{2+}\right)$ ion reduction. Samples were left for $8 \mathrm{~min}$ at $20^{\circ} \mathrm{C}$, and the absorbance at $593 \mathrm{~nm}$, proportional to the ferric reducing capacity, was determined in a UV-visible spectrophotometer (Perkin Elmer UV-vis Lambda 2, Germany). Results were expressed as TE/g d.e., based on the Trolox calibration curve (0-4.5 mg TE/L).

\subsubsection{Scanning electron microscopy (SEM)}

Spray-dried samples were carefully deposited onto carbon tabs (Agar Scientific, Stansted, UK), coated with carbon (Agar turbo carbon coater, Stansted, UK) and placed on the stage of a FEI Quanta 3D
200 dual beam Focused Ion Beam Scanning Electron Microscope (FEI, Hillsboro, Oregon, USA) (Romano, Mobili, Zuñiga-Hansen, \& Gómez-Zavaglia, 2018). Two images per condition were acquired by using secondary electron imaging at an accelerating voltage of $10 \mathrm{kV}$. For each spray-drying condition, the particle size (diameter) was determined on three different regions of each image, using ImageJ program (analyze particles tool; imagej.nih.gov/ij/features.html). The size distribution was determined using a Gaussian distribution model.

\subsubsection{Characterization of fatty acids}

Fifty milligrams of spray-dried samples were transferred into glass test tubes $(13 \times 100 \mathrm{~mm})$ and derivatized, according to Park and Goins (1994). Samples before spray-drying (Section 2.2) were used as control. Briefly, the fatty acids methyl esters (FAME) were prepared by adding $100 \mu \mathrm{L}$ methylene chloride and $1 \mathrm{~mL}$ of $0.5 \mathrm{~N} \mathrm{NaOH}$ in methanol to each tube, heating at $90^{\circ} \mathrm{C}$ for $10 \mathrm{~min}$. After cooling to $25^{\circ} \mathrm{C}, 1 \mathrm{~mL}$ of $14 \% \mathrm{v} / \mathrm{v} \mathrm{BF}_{3}$ (Sigma-Aldrich, Missouri, USA) in methanol were added and heated at $90{ }^{\circ} \mathrm{C}$ for $10 \mathrm{~min}$. The tubes were removed and cooled at $25{ }^{\circ} \mathrm{C}$. FAME were extracted by vigorous shaking for about $1 \mathrm{~min}$ and centrifugation. The upper phase was filtered through $0.22 \mu \mathrm{m}$ nylon filter. Then, the FAME were analyzed on a gas chromatograph interfaced with a mass spectrometer detector (Agilent Technologies 7890A, DE, USA) using capillary column DB-23 (30 $\mathrm{m} \times 0.25 \mathrm{~mm} \times 250 \mu \mathrm{m})$. The analysis conditions were: injection at $250{ }^{\circ} \mathrm{C}$, detector at $280{ }^{\circ} \mathrm{C}$, and column at $50{ }^{\circ} \mathrm{C}$ initially, increasing up to $175^{\circ} \mathrm{C}$ at $25^{\circ} \mathrm{C} / \mathrm{min}$ (ramp 1) and then cooled down from 175 to $230{ }^{\circ} \mathrm{C}$ at $4{ }^{\circ} \mathrm{C} / \mathrm{min}$ (ramp 2) (Quintana, Gerbino, \& Gómez-Zavaglia, 2017).

The fatty acids' composition was determined by considering the relative contribution of each peak area with regard to the sum of the areas corresponding to all the peaks. Results were expressed as percentage of the total area. An external FAME standard was used (Supelco 37 component FAME MIX, Sigma Aldrich, Missouri, USA).

\subsubsection{Attenuated Total Reflectance Fourier Transform Infrared Spectroscopy (ATR-FTIR)}

2.3.6.1. Spray-dried samples Three milligrams of spray-dried samples were placed on the sample holder of an ATR-FTIR Thermo Nicolet iS10 spectrometer (Thermo Scientific, MA, USA). The spectra were registered in the $4000-500 \mathrm{~cm}^{-1}$ range by co-adding 16 scans with $4 \mathrm{~cm}^{-1}$ spectral resolution at $20^{\circ} \mathrm{C}$, using OMNIC software (version 8.3, Thermo Scientific, MA, USA). For an efficient purging of the equipment, a stream of dry nitrogen was used to remove water and $\mathrm{CO}_{2}$ vapors. In the regions were a great overlap of bands occurred, inverted second derivative spectra were used to estimate the number, position and relative contribution of individual composing elements, with Gaussian-Lorentzian band profiles, using OMNIC 9.2.106 (Thermo Fisher Scientific Inc. MA, USA). For a structural analysis of starch (main component of spray-dried samples), the study was focused on the fingerprint region for carbohydrates (1200-900 $\mathrm{cm}^{-1}$ ). Inverted second derivative spectra were used to estimate the number, position and relative contribution of individual elements composing the $1070-950 \mathrm{~cm}^{-1}$ region, and this information was taken into account to fit the most relevant starch bands in the spectra with Gaussian-Lorentzian band profiles, using the program OMNIC (Nicolet Instrument Co., USA).

2.3.6.2. Structure of quinoa proteins In a parallel assay, three grams of spray-dried samples were suspended in $30 \mathrm{~mL}$ distilled water and adjusted to pH 9 with $2 \mathrm{~N} \mathrm{NaOH}$. Suspensions were stirred for $1 \mathrm{~h}$ at $20{ }^{\circ} \mathrm{C}$, and centrifuged at $6000 \mathrm{~g}$ and $25^{\circ} \mathrm{C}$ for $30 \mathrm{~min}$. The supernatants were acidified to $\mathrm{pH} 4.5$ with $\mathrm{HCl}$ (isoelectric point of quinoa proteins) to precipitate proteins (Elsohaimy et al., 2015), and centrifuged at $10,000 \mathrm{~g}$ for $40 \mathrm{~min}$ at $4{ }^{\circ} \mathrm{C}$. The pellets were collected and resuspended in $10 \mathrm{~mL}$ PBS to achieve a concentration of $100 \mathrm{mg} / \mathrm{mL}$. The FTIR spectra of the obtained samples, mainly composed of quinoa proteins, 
were registered in the same conditions as those described above. In this latter case, second derivative spectra were determined using OMNIC software (version 9.2.86 Thermo Scientific, MA, USA). The similarities of the second-derivative spectra in the amide I and II regions were calculated using the QC (Comparison function) tool, according to Jiang, Han, and Cai (2010). In all cases, at least four independent samples were used to assess the reproducibility of results.

\subsubsection{Differential scanning calorimetry (DSC)}

Quinoa starch was extracted by resuspending the spray-dried samples in distilled water, and centrifuging $\left(6000 \mathrm{~g}\right.$ and $\left.25^{\circ} \mathrm{C}\right)$. The process was repeated 3 times until the starch sediment did not further increase. Samples were heated at $10{ }^{\circ} \mathrm{C} / \mathrm{min}$ up to $120{ }^{\circ} \mathrm{C}$ in a DSC equipment (Q100 TA Instruments, USA). As a reference, an empty pan was used and calibration with indium was performed. Peaks corresponding to starch gelatinization were analyzed. For each peak, onset $\left(T_{0}\right)$, peak $\left(T_{p}\right)$ and final temperatures $\left(\mathrm{T}_{\mathrm{f}}\right)$ were calculated as well as enthalpy value (Correa \& Ferrero, 2015).

\subsection{Statistical analysis}

All experiments were performed on triplicate. The relative differences were reproducible irrespective of sample used. Analysis of variance (ANOVA) was used to analyze the results obtained using the statistical program Infostat v2009 software (Córdoba, Argentina). Comparison of means by Fisher LSD mean were tested, and if $p<0.05$ the difference was considered statistically significant.

A principal component analysis (PCA) was carried to evaluate the effect of each spray-drying condition on the physico-chemical parameters of the dehydrated soluble extracts (i.e., $\mathrm{a}_{\mathrm{w}}$, total solids content, WI, TPC, $\mathrm{ABTS}^{\bullet}{ }^{+}$, FRAP, FAME, QC, and \% starch gelatinization) (Origin 2017 v9.4, OriginLab Northampton, Massachusetts, USA).

\section{Results and discussion}

\subsection{Proximate composition and spray-drying set-up}

The proximate composition of the soluble fraction was similar to that of quinoa flour in the content of proteins, lipids and total carbohydrates ( $p>0.05$ ), which were about 14-16 g/100 g d.b., 6-7 g/ $100 \mathrm{~g}$ d.b., and 64-67 g/100 g d.b., respectively (Table S1), in agreement with the already reported composition for quinoa (Abugoch, 2009; Rodríguez, Rolandelli, \& Buera, 2019). Regarding moisture content, quinoa flour represented about $4.5 \%$ of the total flour sample, quite lower than that reported in bibliography (Abugoch, 2009), but at this point it is important to remind that to obtain quinoa flour, the grains were dried before milling. About $40 \mathrm{~g}$ of extract powders were obtained from $100 \mathrm{~g}$ of flour. The concentration of whole fiber in the soluble fraction was lower than that in the flour, as result of the partial removal of insoluble fiber (mainly from the seed coats) in the obtaining process of such fraction (insoluble fiber was: $7.4 \mathrm{~g} / 100 \mathrm{~g}$ d.b. for the dehydrated soluble fraction, and $7.8 \mathrm{~g} / 100 \mathrm{~g}$ d.b for the flour). The higher concentration of ashes in the soluble fraction $(\mathrm{p}<0.05)$ can be ascribed to the solubilization of certain minerals at pH 9 (Section 2.1.2). It was reported that the main minerals present in quinoa flour are potassium, magnesium and calcium, with lower concentrations of phosphorous and iron (Abugoch, 2009; Ballester-Sánchez, Millán-Linares, Fernández-Espinar, \& Haros, 2019). The bioavailability of minerals (in particular calcium) in fiber containing products is an important problem, especially for vegan consumers. The main reason for the low bioavailability of minerals is that they are generally bound to certain fiber constituents (i.e., phytates), leading to insoluble complexes (Kiewlicz \& Rybicka, 2020). Quinoa contains greater amounts of phytates than other related products (i.e., barley, wheat, rice) (Abugoch, 2009; Ballester-Sánchez et al., 2019). As the soluble frac- tion was obtained by solubilizing quinoa flour at $\mathrm{pH} 9$, some of the minerals could have been released. In this regard, $\mathrm{Ca}(\mathrm{OH})_{2}$ is soluble even at $\mathrm{pH} 13$ and $\mathrm{Mg}(\mathrm{OH})_{2}$ is partially soluble at $\mathrm{pH} 9$ (Miller \& Witt, 1929). Moreover, phosphate groups, mainly linked to phytates, might be hydrolyzed at alkaline $\mathrm{pH}$. All these factors can contribute to the increase of the ashes' content of the soluble fraction (Table S1).

Regarding drying process, the drying yield was within 55 and $85 \%$ (d.b.) in all the conditions assayed (Fig. 1A,B). Increasing the inlet air temperature enhanced the drying yields (Fig. 1A), and this can be ascribed to the greater efficiency of heat and mass transfer processes occurring at higher temperatures. Although the outlet temperature resulted in a narrow range within 90 and $99^{\circ} \mathrm{C}$ (Fig. 1C,D), it is interesting to analyze the thermal delta between the inlet and outlet temperature (main driving force for the drying process) when feed flow was fixed at $4.5 \mathrm{~mL} / \mathrm{min}$. In this sense, it presented the same tendency as the drying yield, ranging from 68 to $85{ }^{\circ} \mathrm{C}$. Also, this efficiency of heat and mass transfer, avoids hitting drying particles to the spray-dryer chamber wall (Tontul \& Topuz, 2017a, 2017b). On the other hand, increasing the feed flow from 4.5 to $7.5 \mathrm{~mL} / \mathrm{min}$ had no effect on the drying yield when the inlet temperature was fixed at $180{ }^{\circ} \mathrm{C}$ (Fig. 1B). However, a higher value $(10.5 \mathrm{~mL} / \mathrm{min})$ dramatically decreased the drying yield. This can be attributed to the sticking of the product to the chamber wall, mainly because of the fact that when droplets circulate at high speed, the thermal delta between the inlet and outlet temperature is no longer the only limiting factor for heat and mass transfer process efficiency. Therefore, the compromise between the thermal driving force and the residence time of the product in the drying chamber will determine the final yield of the process. It is important to remark that the spray-dryer used in this work operates in co-current flow, meaning that when the product enters in the drying rate it is exposed to the highest air temperature, and then as it flows down through the chamber, the air temperature decreases. This is consistent with the results shown in Table 1, where the solids' content decreased when increasing the feed flow, revealing that a more humid powder was obtained when operating at $10 \mathrm{~mL} / \mathrm{min}$. Finally, the inlet temperature and feed flow had no effect on the $\mathrm{a}_{\mathrm{w}}$ in none of the conditions assayed, as the $\mathrm{a}_{\mathrm{w}}$ was below 0.135 and results were not significantly different among samples (Table 1).

Taking into account the spray-drying parameters, the solids' content and $\mathrm{a}_{\mathrm{w}}$ as a whole, the best compromise solution to achieve a high powder yield with high solids' content was to combine a high inlet temperature $\left(180^{\circ} \mathrm{C}\right)$ with a moderate feed flow $(7.5 \mathrm{~mL} / \mathrm{min})$ (Fig. 1B). As the most important value of this work was to analyze whether the nutritionally relevant quinoa components remain unchanged upon spray-drying, the obtained results were useful for a preliminary screening of samples.

\subsection{Color and antioxidant activity}

These color parameters ( $\mathrm{L}^{*}, \mathrm{a}^{*}$ and $\mathrm{b}^{*}$ ) can be used to evaluate color changes associated to technological processes. Thermal treatments can lead to browning reactions and quinoa soluble fraction is particularly prompt to such reactions because of the presence of reducing sugars (in particular, maltose arising from the partial hydrolysis of starch, and also D-xylose and glucose) (Ogungbenle, 2003; Pellegrini et al., 2018) and aminoacids (Abugoch, 2009). In spite of that, all the powders analyzed in this work had a whitish color (Fig. 2), their color parameters ranging within [82-88], [-0.31.1] and [11-15] for $L^{*}$, $a^{*}$ and $b^{*}$, respectively (not shown). In order to corroborate this observation, WI, which integrates the three CIELab coordinates values ( $\left.\mathrm{L}^{*}, \mathrm{a}^{*}, \mathrm{~b}^{*}\right)$, was calculated to evaluate the extent of discoloration (browning) during the drying process. These values were within 79.8 and 83.3 , notwithstanding the spray-drying condition assayed, but significantly different to that of quinoa flour $(W I=77.3 \pm 1.0)($ 

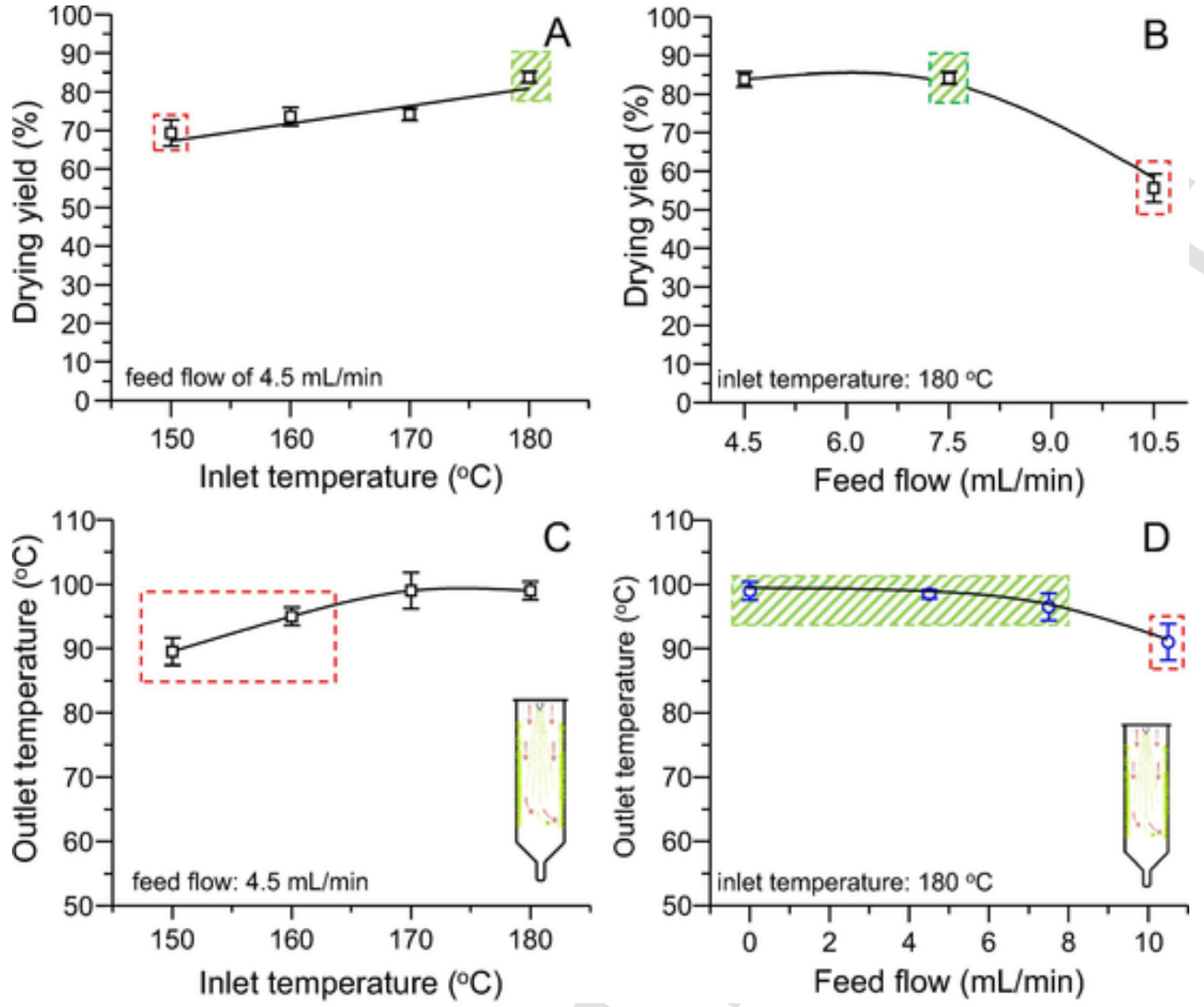

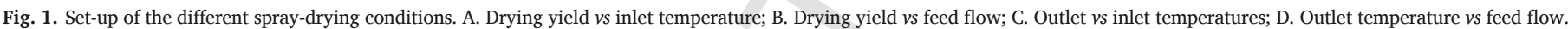

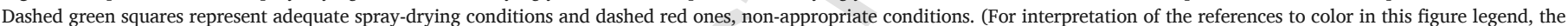
reader is referred to the web version of this article.)

Table 1

Physical and chemical characterization of quinoa flour and soluble fraction after spray-drying ${ }^{1,2}$.

\begin{tabular}{|c|c|c|c|c|c|c|c|c|c|c|}
\hline \multicolumn{2}{|l|}{ Drying condition } & \multirow[t]{2}{*}{ Total solids } & \multirow[t]{2}{*}{$a_{w}$} & \multirow[t]{2}{*}{ WI } & \multirow{2}{*}{$\begin{array}{l}\text { TPC } \\
\text { (mg GAE/g } \\
\text { d.e) }\end{array}$} & \multirow{2}{*}{$\begin{array}{l}\mathrm{ABTS}^{\bullet+} \\
(\mu \mathrm{mol} \mathrm{TE} / \mathrm{g} \\
\text { d.e })\end{array}$} & \multirow{2}{*}{$\begin{array}{l}\text { FRAP } \\
\text { (mg TE/g } \\
\text { d.e) }\end{array}$} & \multirow{2}{*}{$\begin{array}{l}\begin{array}{l}\text { Average } \\
\text { diameter }\end{array} \\
(\mu \mathrm{m})\end{array}$} & \multicolumn{2}{|c|}{ Fatty acids (\%) } \\
\hline $\begin{array}{l}\text { Temperature } \\
\left({ }^{\circ} \mathrm{C}\right)\end{array}$ & $\begin{array}{l}\text { Flow rate } \\
(\mathrm{mL} / \mathrm{min})\end{array}$ & & & & & & & & US & $\mathrm{S}$ \\
\hline 150 & 4.5 & $\begin{array}{l}0.986 \pm 0.001 \\
\text { (a) }\end{array}$ & $\begin{array}{l}0.078 \pm 0.010 \\
\text { (a) }\end{array}$ & $\begin{array}{l}81.5 \pm 0.7 \\
\text { (a) }\end{array}$ & $\begin{array}{l}5.14 \pm 0.20 \\
(a, b)\end{array}$ & $\begin{array}{l}14.21 \pm 0.50 \\
\text { (b) }\end{array}$ & $\begin{array}{l}1.60 \pm 0.07 \\
\text { (a) }\end{array}$ & $\begin{array}{l}12.0 \pm 0.6 \\
\text { (a) }\end{array}$ & 85.83 & 14.17 \\
\hline 160 & 4.5 & $\begin{array}{l}0.987 \pm 0.002 \\
\text { (a) }\end{array}$ & $\begin{array}{l}0.133 \pm 0.054 \\
\text { (a) }\end{array}$ & $\begin{array}{l}82.7 \pm 1.1 \\
\text { (a) }\end{array}$ & $\begin{array}{l}4.85 \pm 0.19 \\
(a, b)\end{array}$ & $\begin{array}{l}12.28 \pm 0.33 \\
\text { (a) }\end{array}$ & $\begin{array}{l}1.61 \pm 0.21 \\
\text { (a) }\end{array}$ & $9.6 \pm 0.8(\mathrm{~b})$ & 87.41 & 12.59 \\
\hline 170 & 4.5 & $\begin{array}{l}0.989 \pm 0.001 \\
\text { (a) }\end{array}$ & $\begin{array}{l}0.083 \pm 0.006 \\
\text { (a) }\end{array}$ & $\begin{array}{l}83.3 \pm 0.6 \\
\text { (b) }\end{array}$ & $\begin{array}{l}4.70 \pm 0.06 \\
\text { (a) }\end{array}$ & $\begin{array}{l}12.08 \pm 0.39 \\
\text { (a) }\end{array}$ & $\begin{array}{l}1.61 \pm 0.19 \\
\text { (a) }\end{array}$ & $\begin{array}{l}12.0 \pm 0.8 \\
\text { (a) }\end{array}$ & 87.33 & 12.67 \\
\hline 180 & 4.5 & $\begin{array}{l}0.998 \pm 0.001 \\
\text { (a) }\end{array}$ & $\begin{array}{l}0.086 \pm 0.000 \\
\text { (a) }\end{array}$ & $\begin{array}{l}81.5 \pm 1.2 \\
\text { (a) }\end{array}$ & $\begin{array}{l}5.01 \pm 0.06 \\
(a, b)\end{array}$ & $\begin{array}{l}12.62 \pm 0.65 \\
\text { (a) }\end{array}$ & $\begin{array}{l}1.65 \pm 0.05 \\
\text { (a) }\end{array}$ & $\begin{array}{l}14.2 \pm 0.1 \\
\text { (c) }\end{array}$ & 87.43 & 12.76 \\
\hline 180 & 7.5 & $\begin{array}{l}0.962 \pm 0.001 \\
\text { (b) }\end{array}$ & $\begin{array}{l}0.047 \pm 0.005 \\
\text { (a) }\end{array}$ & $\begin{array}{l}79.8 \pm 0.8 \\
\text { (a) }\end{array}$ & $\begin{array}{l}5.27 \pm 0.04 \\
\text { (b) }\end{array}$ & $\begin{array}{l}13.74 \pm 0.06 \\
(\mathrm{a}, \mathrm{b})\end{array}$ & $\begin{array}{l}2.12 \pm 0.13 \\
\text { (b) }\end{array}$ & $\begin{array}{l}10.3 \pm 1.8 \\
\text { (b) }\end{array}$ & 87.70 & 12.31 \\
\hline 180 & 10.5 & $\begin{array}{l}0.956 \pm 0.005 \\
\text { (c) }\end{array}$ & $\begin{array}{l}0.069 \pm 0.035 \\
\text { (a) }\end{array}$ & $\begin{array}{l}80.4 \pm 1.1 \\
\text { (a) }\end{array}$ & $\begin{array}{l}5.12 \pm 0.13 \\
(a, b)\end{array}$ & $\begin{array}{l}15.55 \pm 0.28 \\
\text { (c) }\end{array}$ & $\begin{array}{l}1.55 \pm 0.11 \\
\text { (a) }\end{array}$ & $\begin{array}{l}20.0 \pm 1.4 \\
\text { (d) }\end{array}$ & 87.50 & 12.33 \\
\hline Flour control & & $\begin{array}{l}0.960 \pm 0.009 \\
\text { (c) }\end{array}$ & $\begin{array}{l}0.340 \pm 0.070 \\
\text { (b) }\end{array}$ & $\begin{array}{l}77.3 \pm 1.0 \\
\text { (c) }\end{array}$ & $\begin{array}{l}3.01 \pm 0.07 \\
\text { (d) }\end{array}$ & $\begin{array}{l}11.33 \pm 0.74 \\
\text { (d) }\end{array}$ & $\begin{array}{l}1.28 \pm 0.05 \\
\text { (d) }\end{array}$ & $\begin{array}{l}17.9 \pm 4.8 \\
\text { (e) }\end{array}$ & 86.87 & 12.04 \\
\hline
\end{tabular}

1 Values represent means \pm standard deviation of three replicates. Different letters indicate significant differences (p $<0.05)$.

${ }^{2} \mathrm{a}_{\mathrm{w}}$, water activity; WI, whiteness index; TPC, total phenolic compounds; ABTS ${ }^{\bullet+}, 2,2^{\prime}$-azino-bis(3-ethylbenzothiazoline-6-sulphonic acid radical cation; FRAP, ferric ion reducing antioxidant power; US: unsaturated; S: saturated fatty acids.

Table 1). This can be explained given that quinoa flour also contained insoluble fiber (which was removed to obtain the soluble fraction), often associated to darker particles (Fig. 2) (Atwell, 2002; Chan, Hesse, Arndt, \& Marquart, 2009; Herawati, Miftakhussolikhah, Pusporini, \& Murdiati, 2019). Similar values of WI were reported by Hsu et al. (2003), who analyzed the effect of different drying process on white yam flour. Keeping in mind that color is a quality attribute that often influences the perception of other attributes such as flavor or texture on a consumer's opinion (Pathare et al., 2013), a neutral homogeneous whitish color ingredient provides the versatility to be amalgamated to different kinds of food products without modifying their original color. 

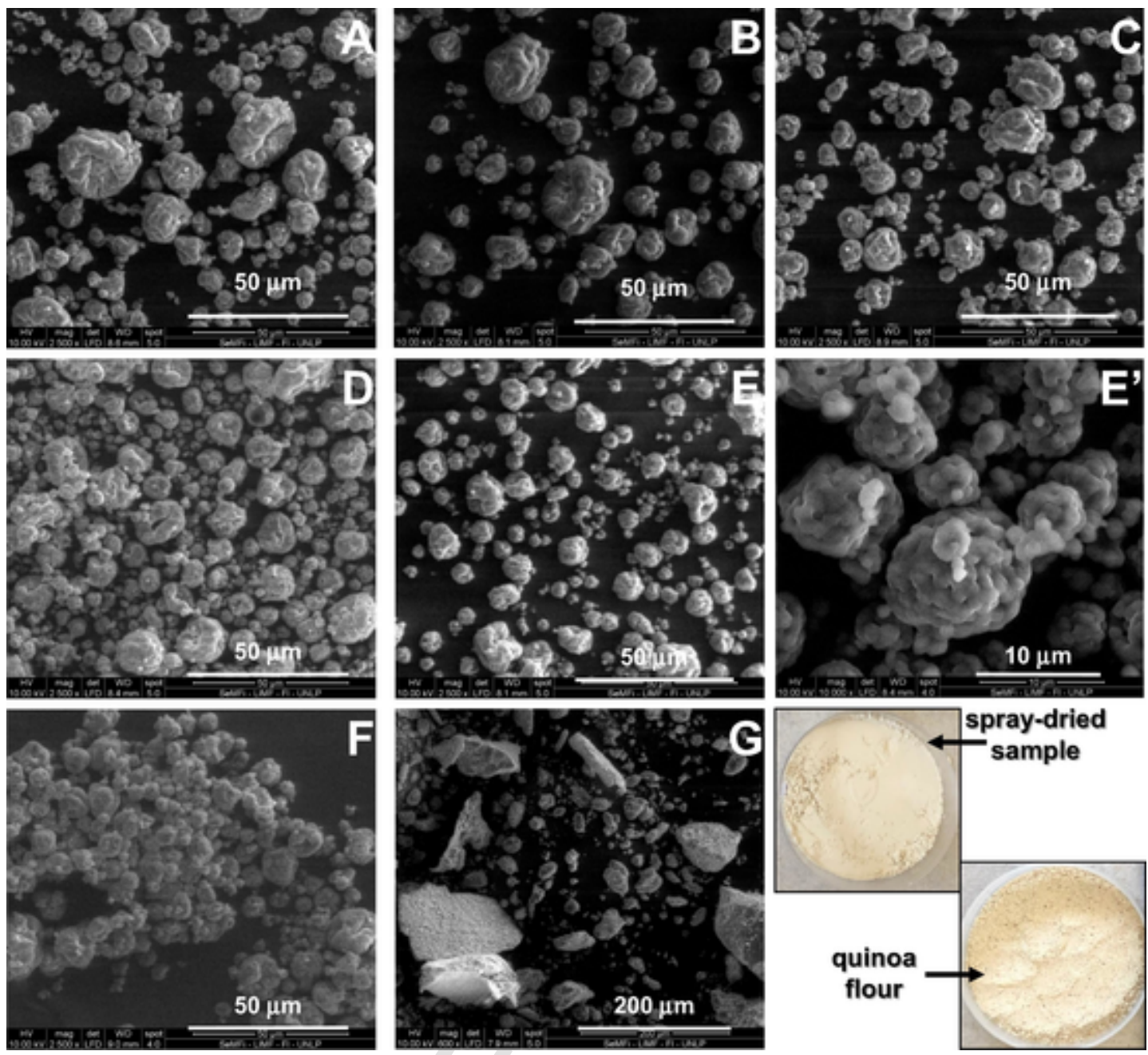

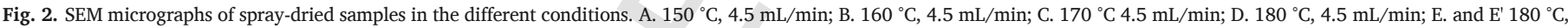

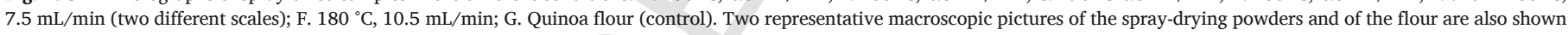
in the lower right corner of the figure.

Table 1 also shows the TPC and the antioxidant activity of spray-dried samples, as determined by the TPC, $\mathrm{ABTS}^{\bullet+}$ and FRAP assays. The first observation was that spray-dried samples had significantly higher TPC and antioxidant activity than quinoa flour (used as control), no matter the spray-drying conditions. In this regard, it should be remained that the processing conditions do not always result in the destruction of antioxidant compounds. Xu and Chang (2008) reported that the exposure of black soybeans to steaming processes leads to the increase of phenolic compounds and antioxidant activity. In addition, cooking (included boiling and steaming) was found to increase the content of phenolic compounds in green beans pepper, and broccoli (Turkmen, Sari, \& Velioglu, 2005). This was ascribed to the release of phenolic or phenolic analogue substances, as well as to the formation of novel compounds with an increased antioxidant activity, as result of the thermal treatment (Kang, Kim, Pyo, \& Yokozawa, 2006; Xu \& Chang, 2008). Although no references about the effect of spray-drying conditions (inlet temperatures and flow rates) on the antioxidant activity of seeds could be found, quinoa samples exposed to spray-drying conditions could experience a similar behavior. In this regard, it was reported that the antioxidant activity of methanolic extracts from different cereals and pseudocereals (amaranth, quinoa, buckwheat and wheat), after baking breads formulated with them, followed the same trend (Alvarez-Jubete, Wijngaard, Arendt, \& Gallagher, 2010).
When analyzing the effect of the inlet temperature on the antioxidant activity, no significant differences were observed at inlet temperatures within 150 and $180{ }^{\circ} \mathrm{C}(\mathrm{p}>0.05)$. When analyzing different flow rates at $180{ }^{\circ} \mathrm{C}$, a moderate increase of the feed flow (i.e., $7.5 \mathrm{~mL} / \mathrm{min}$ ) significantly increased the TPC and FRAP values. At the highest feed flow $(10.5 \mathrm{~mL} / \mathrm{min})$, these values were not significantly different from those determined at $4.5 \mathrm{~mL} / \mathrm{min}$. As a whole, these results indicate that the inlet temperature does not have a detrimental effect on antioxidant compounds and a moderate increase of the feed flow $(7.5 \mathrm{~mL} / \mathrm{min})$ can enhance even more their antioxidant activity (Table 1).

\subsection{Microstructure}

The effect of spray-drying conditions on the microstructure and main macromolecules present in quinoa samples were further investigated. Fig. 2 depicts the SEM images corresponding to the spray-dried powders in different conditions. The average diameters of the particles obtained after spray-drying are shown in Table 1. Spray-dried samples had larger particles than quinoa flour before spray-drying (control), as result of the swelling and agglomeration of starch during the process. The higher diameters observed at high flow rates $(10 \mathrm{~mL} / \mathrm{min})$ can be ascribed to the greater humidity in the vacuum chamber in this condition. A moderate agglomeration, as that observed when the flow rate was 7.5 and $4.5 \mathrm{~mL} / \mathrm{min}$, at the four inlet temperatures assayed, 
can provide technological advantages at an industrial level (Buffo, Probst, Zehentbauer, Luo, \& Reineccius, 2002; Tontul \& Topuz, 2017a, 2017b; Vicente, Pinto, Menezes, \& Gaspar, 2013) because the systematic production of agglomerates with closely specified properties (as result of the spray-drying process) leads samples to dissolve or disperse more readily in liquids than the original material. Hence, as result of the spray-drying process the products will be more wettable (easier penetration of liquids into the pore system of the powder), sinkable (easier sinkability of particles below the liquid surface), dispersible (dispersion with less stirring), and soluble.

When the different spray-drying conditions were compared, no clear trend was observed (Table 1 and Fig. 2A-E). However, increasing the flow rate up to the highest value assayed $(10 \mathrm{~mL} / \mathrm{min})$ led to highly agglomerated particles (Table 1 and Fig. 2F), consistently with the lower content of solids, resulting from the lower efficiency of the heat and mass transfer process when droplets circulate at the highest flow rate (Table 1) (Gharsallaoui et al., 2007; Vicente et al., 2017). In turn, quinoa flour was heterogeneous as result of grinding, and soluble and insoluble materials could not be clearly discriminated by SEM. For this reason, the image of quinoa flour was shown in a larger scale, where geometric forms of non-gelatinized starch could be observed (Fig. 2G).

Spray-dried dairy powders are common ingredients in many food and dairy products. The flowability of these powders is an important attribute for an ease of handling, processing in the final application. The flowability generally depends on physical properties of the powder, such as particle size and shape, surface structure, particle density, bulk density, moisture content and fat content. Despite the likely influence of these parameters, the flowability of powders is a surface related property and is therefore thought to be influenced to some extent by the powder surface composition (Kim, Xiao, \& Pearce, 2005). It must be considered that although high agglomeration will negatively affect the powder fluidity, agglomeration of small diameter particles will facilitate further solubilization, not affecting the powder fluidity. Therefore, a compromise solution must be considered (Chatterjee, Gupta, \& Srivastava, 2017). In addition, a controlled agglomeration can be used to improve the flowability and solubility of amorphous structures having very low flowability, such as amorphous inulin (Romano et al., 2018).

\subsection{Stability of lipids and proteins}

The fatty acid composition of non-dehydrated quinoa flour samples (controls) was mainly composed of unsaturated and polyunsaturated fatty acids, together with palmitic acid (C16:0), in agreement with the results reported for quinoa seeds (Abugoch, 2009). Unsaturated and polyunsaturated were close to $90 \%$ of the total fatty acids and mainly included oleic and linoleic fatty acids, with lower amounts of linolenic acid (Tables 1 and S2). Although unsaturated and polyunsaturated fatty acids are susceptible to oxidation as result of thermal processes (Javed, Imran, Ahmad, \& Hussain, 2018), no alterations in the unsaturated/ polyunsaturated fatty acids ratio were observed after spray-drying in the different conditions (Table 1). The effect of spray-drying conditions on the stability of fatty acids was recently evaluated on designer eggs (Javed et al., 2018). In spite of the fact that the spray-drying conditions were not exactly the same as those used in this work (inlet temperature, $199{ }^{\circ} \mathrm{C}$; flow rate, $6.65 \mathrm{~mL} / \mathrm{min}$; outlet temperature, $76-77^{\circ} \mathrm{C}$ ), the authors underlined that the inlet and outlet air temperature are the major factors affecting the essential fatty acids content of spray-dried samples. The stability of quinoa fatty acids upon spray-drying can be ascribed to different aspects. The spherical aggregates formed during spray-drying (see Section 3.3) produced from the small starch granules allowed a compact packing (Hoyos-Leyva, Bello-Perez, Alvarez-Ramirez, \& García, 2018). The amylose present in quinoa starch has the ability of forming complexes with small molecules because the amylose helices have a hydrophylic outer surface and a hydrophobic helical channel where hydrophobic compounds, such as fatty acids, can be accommodated (Immel \& Lichtenthaler, 2000). This represents an advantage of starch with high amylose content to encapsulate hydrophobic compounds. Considering that quinoa is rich in essential fatty acids (i.e., omega-6 and omega-3), their stability upon spray-drying is a very important result, supporting their use for the production of dehydrated quinoa, to be incorporated in the formulation of functional foods.

To evaluate the stability of proteins after spray-drying, the powders were rehydrated at $\mathrm{pH} 9$ to allow their extraction (Section 2.3.6.2). This way, samples rich in proteins were obtained; the corresponding spectra are shown in Fig. S1. Even if all spectra were dominated by protein bands, some of the bands/shoulders could be unequivocally ascribed to lipids and carbohydrates. The bands in the $3700-3000 \mathrm{~cm}^{-1}$ region arose from $\mathrm{\nu OH}$ vibrational modes, corresponding to $\mathrm{OH}$ groups from proteins (quinoa proteins are rich in aminoacids with amino and hydroxyl groups, such as glutamic, threonine and lysine) (Abugoch, 2009), or soluble carbohydrates, including soluble fiber. The $2960-2850 \mathrm{~cm}^{-1}$ region was dominated by the typical narrow shapedbands arising from the $\nu \mathrm{CH}_{2}$ and $\nu \mathrm{CH}_{3}$ vibrational modes of lipids (Díaz, Ale, Ben Altabef, Tymczyszyn, \& Gomez-Zavaglia, 2017), with the contribution of $\mathrm{CH}_{2}$ groups present in proteins (Fig. S1). In turn, the band/shoulder at $1744 \mathrm{~cm}^{-1}$ arose from the $\nu \mathrm{C}=\mathrm{O}$ vibrational mode of lipids (Díaz et al., 2017) and did not show differences among samples. Amide I and amide II bands occurred in the $1700-1480 \mathrm{~cm}^{-1}$ region. Amide I bands result from the absorption of $c a$. $80 \%$ of the $\nu \mathrm{C}=$ $\mathrm{O}$ vibrational mode of the peptide bonds and are generally used to determine the secondary structure of proteins (Mobili, Londero, Maria, Eusebio, De Antoni, Fausto, \& Gomez-Zavaglia, 2009). Amide II band arises from $\nu$ C-N (ca. 40\%) strongly coupled with out of plane $\delta \mathrm{N}-\mathrm{H}(\mathrm{ca} .60 \%)$ vibrational modes (Mobili et al., 2009). The two bands observed in the $1480-1344 \mathrm{~cm}^{-1}$ region arose from the $\delta \mathrm{CH}$ vibrational modes of proteins and lipids. As they are not specific bands, they result large and difficult to be unambiguously ascribed. The band at $1237 \mathrm{~cm}^{-1}$ is the result of amide III, arising from $\nu \mathrm{C}-\mathrm{H}(\mathrm{ca}$. 60\%) coupled with in plane $\delta \mathrm{N}-\mathrm{H}$ (ca. $40 \%$ ), with some contribution of $\nu_{\mathrm{as}} \mathrm{PO}_{2}{ }^{-}$vibrational mode from lipids, also absorbing in this region (Fig. S1) (Díaz et al., 2017). Finally, the region below $1200 \mathrm{~cm}^{-1}$ is very unspecific as it is the result of a mixture of weak bands from lipids, proteins and carbohydrates. In fact, these bands can be ascribed to $\nu_{\mathrm{sym}} \mathrm{PO}_{2}{ }^{-}$phosphate groups from lipids ( $c a$. $1080 \mathrm{~cm}^{-1}$ ), $\nu \mathrm{C}-\mathrm{N}$ from proteins (ca. $1150 \mathrm{~cm}^{-1}$ ), $\delta \mathrm{COC}$ from lipids and carbohydrates ( $c a .1170 \mathrm{~cm}^{-1}$ ), and $\delta \mathrm{COH}$ and the $\nu \mathrm{C}-\mathrm{C}$ from carbohydrates (Díaz et al., 2017; Mobili et al., 2009; Santos, Araujo-Andrade, Tymczyszyn, \& Gómez-Zavaglia, 2014).

Quinoa proteins consist in two major fractions, globulins (11S) and albumins (2S), containing $\alpha$-helices $(\sim 15-16 \%)$; $\beta$-sheets $(\sim 30-32 \%)$; turns $(\sim 20-22 \%)$ and random coil $(\sim 30-34 \%)$, as determined by circular dichroism (Vera, Valenzuela, Yazdani-Pedram, Tapia, \& Abugoch, 2019). The position of amide I of spray-dried samples, at $1633 \mathrm{~cm}^{-1}$, indicates an important contribution of $\beta$-sheet structures (Mobili et al., 2009). To get deeper information about the protein structures of spray-dried samples, a comparative analysis of the second derivative spectra was carried out (Fig. 3). To this aim, the QC tool enabled to correlate the spectral information contained in the amide I and II second derivative spectra with that contained in samples before spray-drying (quinoa flour), giving values within 0 (no correlation) and $100 \%$ (identical spectra) (Jiang et al., 2010). In this work, this strategy enabled to obtain a picture of the effect of spray-drying conditions (temperatures and feed flows) on the structure of all proteins contained in the quinoa samples. When compared the spray-dried samples with the quinoa flour, the percentage of similarity (\%QC) decreased 


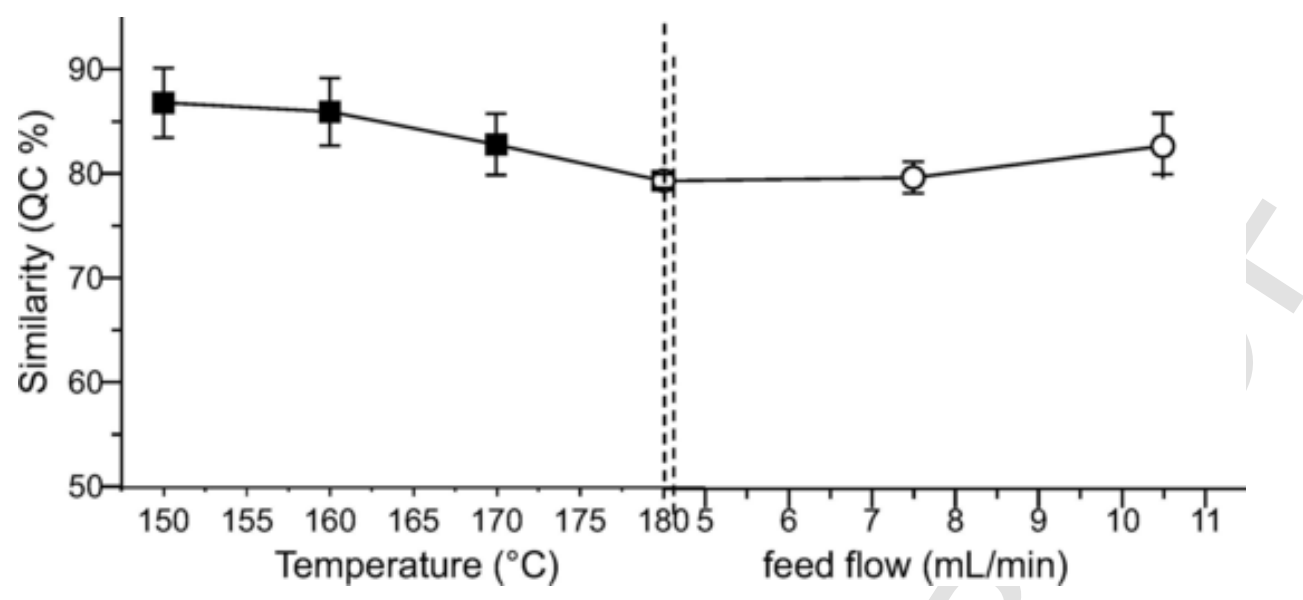

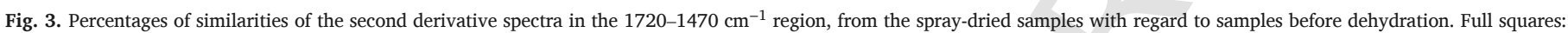
effect of different inlet temperatures at $4.5 \mathrm{~mL} / \mathrm{min}$ feed flow; empty circles, effect of different feed flow values at an inlet temperature of $180{ }^{\circ} \mathrm{C}$.

from $86.79 \pm 3.33 \%$ at $150{ }^{\circ} \mathrm{C}$ to $79.31 \pm 0.65 \%$ at $180{ }^{\circ} \mathrm{C}$ (full squares in Fig. 3), showing some protein damage as result of the increase in the inlet temperature. Increasing the feed flow could counterbalance this effect, as using $10.5 \mathrm{~mL} / \mathrm{min}$ feed flow at $180{ }^{\circ} \mathrm{C}$ had a similar effect as using $170{ }^{\circ} \mathrm{C}$ and $4.5 \mathrm{~mL} / \mathrm{min}$ feed flow $(82.64 \pm 3.15 \%$ and $82.80 \pm 2.94 \%$, respectively; $p>0.05$ ) (empty circles in Fig. 3 ). This points out that thermal damage of proteins is also time dependent, since exposing the droplets to high temperatures but for shorter times (higher speed flow) can produce a similar damage than the combination of lower temperatures and larger times (lower speed flow).

In spite of the differences reported, it must be considered that all spray-dried samples had more than $80 \%$ of similarity with regard to the controls, meaning that the protein structures were not drastically affected by none of the spray-drying conditions.

\subsection{Physico-chemical and structural properties of starch after spray-drying}

Starch is the major component of quinoa carbohydrates and accounts for $32-69 \%$ (Fig. S2). Its physicochemical properties provide it a wide versatility in terms of applications. In particular, gelatinization of starch plays an important role during processing of starch containing products (Abugoch James, 2009), and strongly depends on the starch structure, which in turn is directly related with its physico-chemical properties (i.e., phase transition behavior). Fig. 4A depicts the effect of spray-drying conditions (inlet temperature and feed flow) on the starch melting enthalpies. The melting enthalpies systematically decreased with the increase of the inlet temperature (Fig. 4A), indicating the loss of the crystalline structure of starch as result of hydration and exposure to high temperatures (Ratnayake, Otani, \& Jackson, 2009). In turn, increasing the feed flow leads to an increase in sample humidity (or decrease in the solids' content, see Table 1), which also conducted to a greater gelatinization, as shown by the further decrease in the melting enthalpies at higher feed flows (Fig. 4A,B). The increase of the inlet temperatures led to an increase in the starch gelatinization, and a moderate increase in the feed flow $(7.5 \mathrm{~mL} / \mathrm{min})$ limited such increase. On the contrary, a higher feed flow $(10 \mathrm{~mL} / \mathrm{min})$ increased gelatinization even more than the increase of temperatures (Fig. 4B). As the increase of gelatinization is associated with agglomeration (Warren, Perston, Royall, Butterworth, \& Ellis, 2013), these results are consistent with the SEM images and the starch particle size, reinforcing that a moderate increase of feed flow led to a moderate agglomeration (Fig. 2 and Table 1), which in turn, would facilitate wettability, sinkability, dispersibility and solubility in potential industrial processes (Noora, Sudheesh, Sangeetha, \& Sunooj, 2019).
FTIR spectra provided complementary structural information about the organization of starch in the spray-dried samples (Fig. S3). The $\nu \mathrm{OH}$ vibrational mode was observed at $3304 \mathrm{~cm}^{-1}$ for the controls and $3285 \mathrm{~cm}^{-1}$ for the spray-dried samples. $\mathrm{NOH}$ vibrational mode is very sensitive to the strength of hydrogen bonds, and the greater the shifts the stronger the hydrogen bonds. As the hydrogen bonds established between hydroxyl groups of carbohydrates are much weaker than those established between carbohydrates with water (Santos et al., 2014), the downshift observed for the spray-dried samples can be ascribed to the interaction of spray-dried samples (mainly composed by starch) with water (gelatinization).

The $1250-800 \mathrm{~cm}^{-1}$ region, corresponding to the fingerprint region of sugars (mostly composed of starch in this case) provided much richer information (Fig. S3). This region is particularly sensitive to the physical state of sugars (amorphous or crystalline) and to starch gelatinization (Santos et al., 2014). All samples analyzed were majorly amorphous because of the broad shape of the bands, typical from the disordered amorphous phase (Santos et al., 2014). In particular, the absorbance of the bands at 1150,1080 and $1020 \mathrm{~cm}^{-1}$, arising from $\nu \mathrm{C}-\mathrm{C}$, coupled with $\nu \mathrm{C}-\mathrm{O}, \delta \mathrm{COH}$ and $\nu \mathrm{COC}$ glycosidic bonds, is strongly related with conformational changes associated to gelatinization and indicate chain conformation (short range order) and helicity changes when crystallinity and molecular orientation are lost, that is, in the amorphous state and during gelatinization (Capron, Robert, Colonna, Brogly, \& Planchot, 2007). The observation of all these bands in the FTIR spectra clearly indicates that spray-dried samples are all in the amorphous state (Fig. S3). Particularly relevance acquires the band at $1000 \mathrm{~cm}^{-1}$, which was reported to be sensitive to intramolecular hydrogen bonds of hydroxyl groups or plasticizing effect of water (Capron et al., 2007). In this regard, the $1020 / 1000 \mathrm{~cm}^{-1}$ ratio, was reported to be directly related with gelatinization (Capron et al., 2007). Fig. S4 shows the evolution of this ratio for the spray-dried samples. To determine the $1020 / 1000 \mathrm{~cm}^{-1}$ ratio, peak fitting in the $1070-950 \mathrm{~cm}^{-1}$ region was necessary because of the great overlap of bands (Fig. S5). The evolution of this ratio in Fig. S4 closely followed that of starch gelatinization, shown in Fig. 4. This ratio was reported to be related with short-range ordered molecular structures (Warren, Gidley, \& Flanagan, 2016). As mentioned before, gelatinization of starch involves disruption of molecular organization within the granule, and it is influenced by starch-water interactions as result of the swelling of the starch granules. This swelling leads to the rupture of most inter and intra-hydrogen bonds and hydrophobic bonds. Therefore, it was suggested that changes in the $1020 \mathrm{~cm}^{-1}$ band are related with the exchange of hydrogen bonds between starch and water, which indicates the sol formation naturally occurring be- 

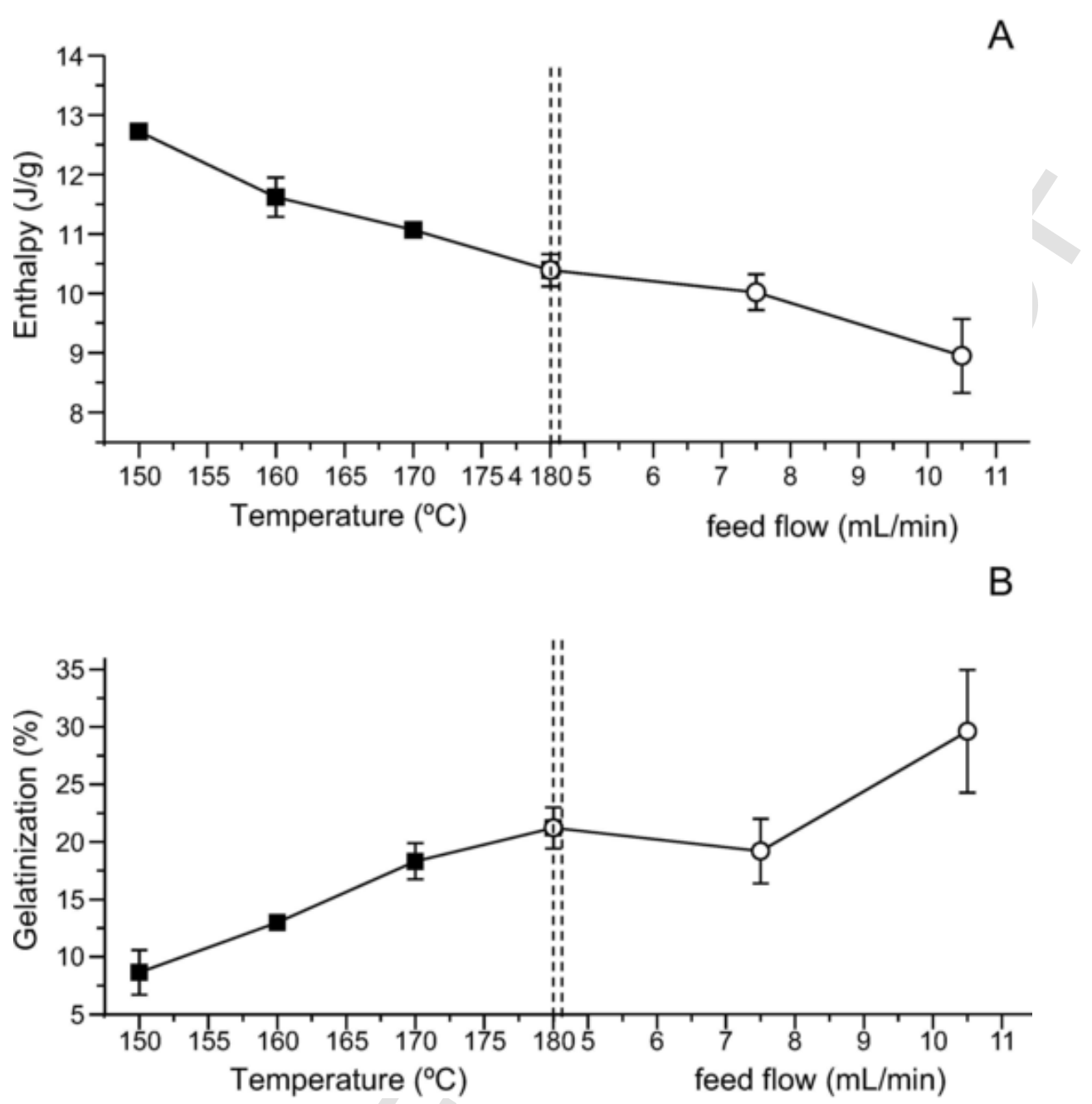

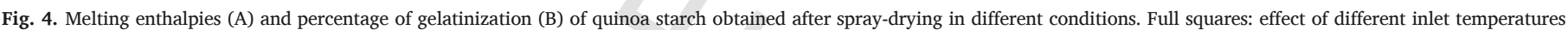
at $4.5 \mathrm{~mL} / \mathrm{min}$ feed flow; empty circles, effect of different feed flow values at an inlet temperature of $180{ }^{\circ} \mathrm{C}$. Enthalpy of the control: $12.72 \pm 0.08 \mathrm{~J} / \mathrm{g}$.

fore gelatinization. For this reason, the 1000/1022 ratio was reported to be associated to water content and has proved to be a useful tool to monitor the loss of structure occurring during gelatinization (Capron et al., 2007).

\subsection{Effect of spray-drying conditions on all the parameters investigated}

In order to obtain a whole picture of the effect of spray-drying conditions on the stability of functional components of quinoa soluble fractions, a PCA was carried out considering all the results presented in Sections 3.1-3.5 (Fig. 5). The first three PC explained more than $85 \%$ of the total variance. PC1, explaining $48 \%$ of the variance, was particularly sensitive to structural changes among samples, that is, differences in proteins, starch, color and water were mainly explained along this PC. In turn, PC2 explained $26 \%$ of the total variance and described differences among sensitive compounds, that is, unsaturated fatty acids, antioxidants and polyphenols (TPC, ABTS ${ }^{\bullet+}$, FRAP) (Fig. 5A). Finally, PC3 explained $13.5 \%$ of the total variance and described differences in antioxidants and gelatinization (Fig. 5B). This relationship probably defines the encapsulating capacity of starch in the systems.

Taking into consideration both PCA, it is remarkable that spray-drying at $150{ }^{\circ} \mathrm{C}$ and $4.5 \mathrm{~mL} / \mathrm{min}$ feed flow is a condition leading to the most different results for all the parameters investigated (Fig. 5A). Changes in the inlet temperature within 160 and $180{ }^{\circ} \mathrm{C}$ at the same feed flow $(4.5 \mathrm{~mL} / \mathrm{min})$ did not show great differences regarding functional parameters, as they grouped together both in PC2 vs PC1 and in PC3 vs PC1 graphs. On the contrary, at high feed flows (i.e., $10.5 \mathrm{~mL} / \mathrm{min}$ ) the parameters related with encapsulation capacity were those most affected (Fig. 5B). However, a moderate increase of the feed flow from 4.5 to $7.5 \mathrm{~mL} / \mathrm{min}$ resulted in an adequate strategy to improve the protection of functional components related with the encapsulation capacity (Fig. 5B). As a whole, it can be concluded that these moderate feed flows appear as a compromise situation to counterbalance the effect of increasing temperatures, thus improving the technological parameters.

\section{Conclusion}

In this work, a spray-dried powder retaining the high nutritional value of quinoa was obtained, namely the content of unsaturated fatty acids, antioxidants, protein structure. From a technological viewpoint the use of moderate feed flows $(7.5 \mathrm{~mL} / \mathrm{min})$ and high inlet temperatures $\left(180^{\circ} \mathrm{C}\right)$ was the best combination to obtain high powder yields, low $\mathrm{a}_{\mathrm{w}}$ and high solids content. The drying temperature affected the structure of starch, the main component in the isolate (ca. 60\%). This appears as an advantage because it increases the encapsulation properties of quinoa as result of the improved swelling and moderate agglomeration gained during the process.

As a whole, it can be concluded that spray-drying is a suitable technique to dry quinoa extracts, retaining their nutritional value and im- 


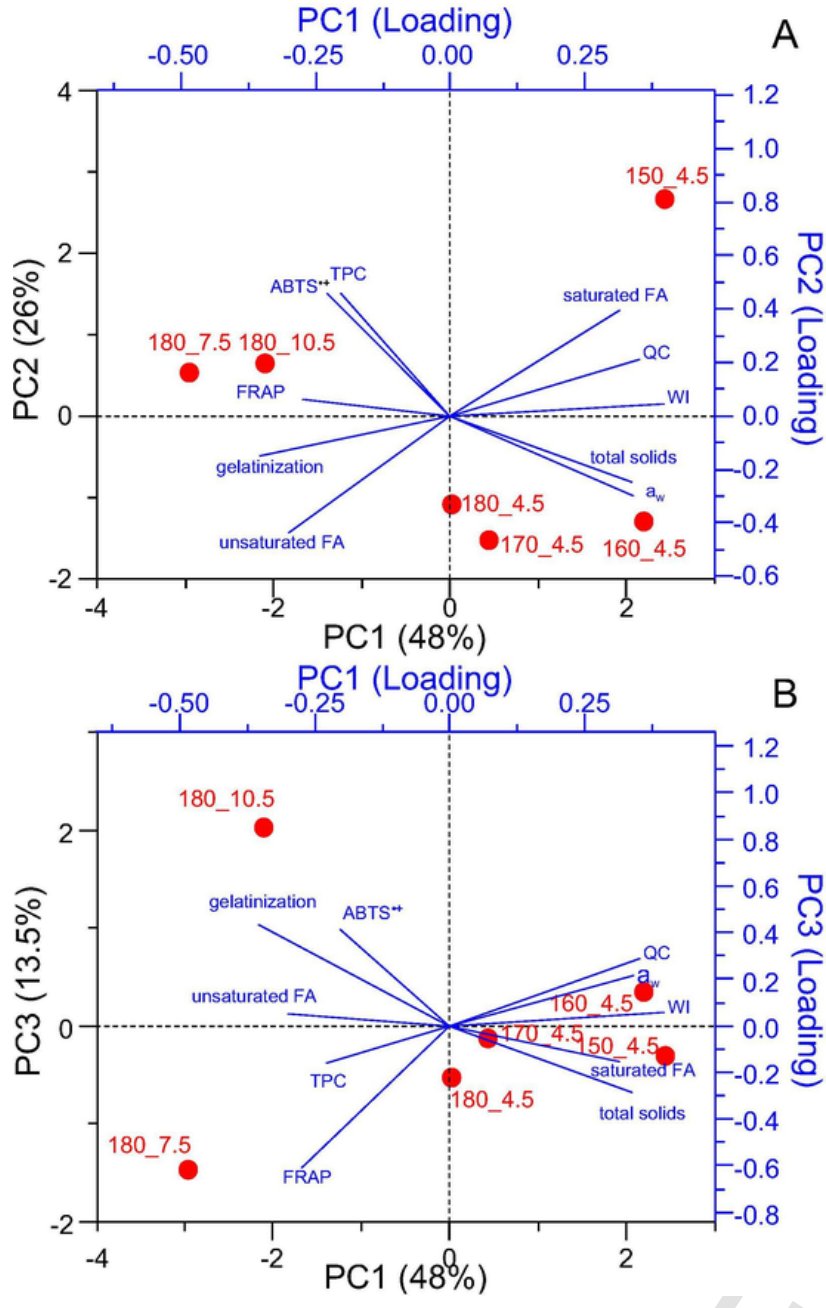

Fig. 5. PCA performed on the soluble fractions of quinoa spray-dried in different conditions. PC2 vs PC1 (A) and PC3 vs PC1 (B). Red circles indicate the different spray-drying conditions. Blue lines indicate the representing parameters. (For interpretation of the references to color in this figure legend, the reader is referred to the web version of this article.)

proving their technological parameters. Taking this into account, the powders obtained in this work could be used as functional ingredients to diversify the offer of quinoa-based products.

\section{Declaration of Competing Interest}

The authors declare that they have no known competing financial interests or personal relationships that could have appeared to influence the work reported in this paper.

\section{Acknowledgements}

This project has received funding from the European Union's Horizon 2020 research and innovation programme under grant agreement $\mathrm{N}^{\circ}$ 777657, and from the Argentinean Agency for the Scientific and Technological Promotion (ANPCyT) (Projects PICT start-up (2016)/4808 and PICT(2017)/1344). Lic. Claudio Reyes, Eng. Javier Lecot, Mariana Pennisi and Lib. Diana Velasco are acknowledged for technical assistance. N.R. and A.G.-Z. are members of the research career CONICET. M.M.U. is postdoctoral fellow from ANPCyT.

\section{Appendix A. Supplementary material}

Supplementary data to this article can be found online at https://doi. org/10.1016/j.foodres.2019.108884.

\section{References}

Abugoch, L. E. (2009). Quinoa (Chenopodium quinoa Willd.): Composition, chemistry, nutritional, and functional properties. Advances in Food and Nutrition Research, 58, 1-31. doi:10.1016/S1043-4526(09)58001-1.

Abugoch, L. E., Romero, N., Tapia, C., Silva, J., \& Rivera, M. (2008). Study of some physic ochemical and functional properties of quinoa (Chenopodium quinoa Willd.) protein isolates. Journal of Agricultural and Food Chemistry, 56, 4745-4750. doi:10.1021/ jf703689u.

Alvarez-Jubete, L., Wijngaard, H., Arendt, E. K., \& Gallagher, E. (2010). Polyphenol composition and in vitro antioxidant activity of amaranth, quinoa buckwheat and wheat as affected by sprouting and baking. Food Chemistry, 119, 770-778. doi:10.1016/ j.foodchem.2009.07.032.

Arribas, C., Cabellos, B., Cuadrado, C., Guillamón, E., \& Pedrosa, M. M. (2019). Extrusion effect on proximate composition, starch and dietary fibre of ready-to-eat products based on rice fortified with carob fruit and bean. Lebensmittel Wissenschaft und Technologie (LWT), 111, 387-393. doi:10.1016/j.lwt.2019.05.064.

Association of Official Analytical Chemists (AOAC) (1995). (16th ed.). Washington, DC, USA.

Atwell, W. (2002). Whole-wheat products: An overview. In Marquart, L., Slavin, J., \& Fulcher, G. (Eds.), Whole grains in health and disease (pp. 125-139). St. Paul, MN: American Association of Cereal Chemists, Eagan Press.

Ballester-Sánchez, J., Millán-Linares, M. C., Fernández-Espinar, M. T., \& Haros, C. M. (2019). Development of healthy, nutritious bakery products by incorporation of quinoa art. no. 379. Foods, 8(9). doi:10.3390/foods8090379.

Benzie, I. F., \& Strain, J. J. (1996). The ferric reducing ability of plasma (FRAP) as a measure of antioxidant power: The FRAP assay. Analytical Biochemistry, 15, 70-76. doi:10.1006/abio.1996.0292.

Bradley, R. L. (2010). Moisture and total solids analysis. Food analysis (pp. 85-104). Boston, MA: Springer.

Buffo, R. A., Probst, K., Zehentbauer, G., Luo, Z., \& Reineccius, G. A. (2002). Effects of agglomeration on the properties of spray-dried encapsulated flavours. Flavour and Fragrance Journal, 17, 292-299. doi:10.1002/ffj.1098.

Capron, I., Robert, P., Colonna, P., Brogly, M., \& Planchot, V. (2007). Starch in rubbery and glassy states by FTIR spectroscopy. Carbohydrate Polymers, 68, 249-259. doi:10.1016/j.foodres.2014.07.040.

Chatterjee, A., Gupta, M. M., \& Srivastava, B. (2017). Spherical crystallization: A technique use to reform solubility and flow property of active pharmaceutical ingredients. International Journal of Pharmaceutical Investigation, 7, 4-9. doi:10.4103/ jphi.JPHI 3616 .

Chan, H. W., Hesse, D., Arndt, E., \& Marquart, L. (2009). Knowledge and practices of school foodservice personnel regarding whole grain foods. Journal of Foodservice, 20, 109-116. doi:10.1111/j.1748-0159.2009.00129.x.

Correa, M. J., \& Ferrero, C. (2015). Thermal behaviour of wheat starch and flour at different water levels: Effect of pectins, modified celluloses and NaCl. Starch/Staerke, 67, 338-347. doi:10.1002/star.201400116.

Díaz, S. B., Ale, N. M., Ben Altabef, A., Tymczyszyn, E., \& Gomez-Zavaglia, A. (2017). Interaction of galacto-oligosaccharides and lactulose with dipalmitoylphosphatidilcholine lipid membranes as determined by infrared spectroscopy. RSC Advances, 7, 24298-24304. doi:10.1039/C7RA01964E.

Elsohaimy, S. A., Refaay, T. M., \& Zaytoun, M. A. M. (2015). Physicochemical and functional properties of quinoa protein isolate. Annals of Agricultural Sciences, 60, 297-305. doi:10.1016/j.aoas.2015.10.007.

Garcia, A., Reis, C., Serpa, J., Viegas, J., Ferreira, M., Almeida, S., .. Tavares, N. (2018). Physical-sensory evaluation of a cereal bar with quinoa: A preliminary study. Journal Biomedical and Biopharmaceutical Research (BBR), 15, 27-38. doi:10.19277/ BBR.15.1.171.

Gharsallaoui, A., Roudaut, G., Chambin, O., Voilley, A., \& Saurel, R. (2007). Applications of spray-drying in microencapsulation of food ingredients: An overview. Food Research International, 40, 1107-1121. doi:10.1016/j.foodres.2007.07.004.

Gürbüz, G., Kauntola, V., Ramos Diaz, J. M., Jouppila, K., \& Heinonen, M. (2018). Oxidative and physical stability of oil-in-water emulsions prepared with quinoa and amaranth proteins. European Food Research and Technology, 244, 469-479. doi:10.1007/ s00217-017-2973-4.

Herawati, E. R. N., Miftakhussolikhah, M., Pusporini, A. R., \& Murdiati, A. (2019). Sensorial and chemical characterization of snack bar with variation of gembolo flour (Dioscorea bulbifera) and arrowroot starch (marantha arundinaceae L.). Food Research, 3, 564-569.

Hoyos-Leyva, J. D., Bello-Perez, L. A., Alvarez-Ramirez, J., \& García, H. S. (2018). Microencapsulation using starch as wall material: A review. Food Reviews International, 34, 148-161. doi:10.1080/87559129.2016.1261298.

Hsu, C., Chen, W., Wenga, Y., \& Tsenga, C. (2003). Chemical composition, physical properties, and antioxidant activities of yam flours as affected by different drying methods. Food Chemistry, 83, 85-92. doi:10.1016/S0308-8146(03)00053-0.

Immel, S., \& Lichtenthaler, F. W. (2000). The hydrophobic topographies of amylose and its blue iodine complex. Starch-Stärke, 52, 1-8. doi:10.1002/(sici)1521-379x(200001). 
Jan, K. N., Panesar, P. S., \& Singh, S. (2018). Optimization of antioxidant activity, textural and sensory characteristics of gluten-free cookies made from whole indian quinoa flour. Lebensmittel Wissenschaft und Technologie- Food Science and Technology, 93, 573-582. doi:10.1016/j.lwt.2018.04.013.

Javed, A., Imran, M., Ahmad, N., \& Hussain, A. I. (2018). Fatty acids characterization and oxidative stability of spray dried designer egg powder. Lipids in Health and Disease, 17, 282-295. doi:10.1186/s12944-018-0931-1.

Jeske, S., Zannini, E., Cronin, M. F., \& Arendt, E. K. (2018). Impact of protease and amylase treatment on proteins and the product quality of a quinoa-based milk substitute. Food and Function, 9, 3500-3508. doi:10.1039/c8fo00336j.

Jiang, Q. Q., Han, Y., \& Cai, X. (2010). Quantum corrections and black hole spectroscopy. Journal of High Energy Physics., 2010, 49. doi:10.1007/jhep08(2010) 049.

Kang, K. S., Kim, H. Y., Pyo, J. S., \& Yokozawa, T. (2006). Increase in the free radical scavenging activity of ginseng by heat-processing. Biological and Pharmaceutical Bulletin, 29, 750-754. doi:10.1248/bpb.29.750.

Kaur, R., Ahluwalia, P., Sachdev, P. A., \& Kaur, A. (2018). Development of gluten-free cereal bar for gluten intolerant population by using quinoa as major ingredient. Journal of Food Science and Technology, 55, 3584-3591. doi:10.1007/s13197-018-3284-x.

Kiewlicz, J., \& Rybicka, I. (2020). Minerals and their bioavailability in relation to dietary fiber, phytates and tannins from gluten and gluten-free flakes. Food Chemistry, 305. doi:10.1016/j.foodchem.2019.125452. art. no. 125452.

Kim, D. O., Jeong, S. W., \& Lee, C. Y. (2003). Antioxidant capacity of phenolic phytochemicals from various cultivars of plums. Food Chemistry, 81, 321-326. doi:10.1016/ S0308-8146(02)00423-5

Kim, E. H.-J., Xiao, D. C., \& Pearce, D. (2005). Effect of surface composition on the flowability of industrial spray-dried dairy powders. Colloids and Surfaces B: Biointerfaces, 46, 182-187. doi:10.1016/j.colsurfb.2005.11.005.

Lorenzo, G., Sosa, M., \& Califano, A. (2018). Alternative proteins and pseudocereals in the development of gluten-free pasta. Alternative and Replacement Foods, 17, 433-458. doi:10.1016/B978-0-12-811446-9.00015-0.

Miller, L. B., \& Witt, J. C. (1929). Solubility of calcium hydroxide. Journal of Physical Chemistry, 33, 285-289. doi:10.1021/j150296a010.

Mobili, P., Londero, A., Maria, T. M. R., Eusébio, M. E. S., De Antoni, G. L., Fausto, R., \& Gómez-Zavaglia, A. (2009). Characterization of S-layer proteins of Lactobacillus by FTIR spectroscopy and differential scanning calorimetry. Vibrational Spectroscopy, 50, 68-77. doi:10.1016/j.vibspec.2008.07.016.

Mota, C., Santos, M., Mauro, R., Samman, N., Matos, A. S., Torres, D., \& Castanheira, I. (2016). Protein content and amino acids profile of pseudocereals. Food Chemistry, 193, 55-61. doi:10.1016/j.foodchem.2014.11.043.

Noora, B., Sudheesh, C., Sangeetha, N., \& Sunooj, K. V. (2019). Effect of isolation methods on the crystalline, pasting, thermal properties and antioxidant activity of starch from queen sago (Cycas circinalis) seed. Journal of Food Measurement and Characterization, 13, 2147-2156. doi:10.1007/s11694-019-00135-2.

Ogungbenle, H. N. (2003). Nutritional evaluation and functional properties of quinoa (Chenopodium quinoa) flour. International Journal of Food Sciences and Nutrition, 54, 153-158. doi:10.1080/0963748031000084106.

Park, P. W., \& Goins, R. E. (1994). In situ preparation of fatty acid methyl esters for analysis of fatty acid composition in foods. Journal of Food Science, 59, 1262-1266. doi:10.1111/j.1365-2621.1994.tb14691.x.

Pathare, P. B., Opara, U. L., \& Al-Julanda Al-Said, F. (2013). Colour measurement and analysis in fresh and processed foods: A Review. Food Bioprocess Technology, 6, 36-60. doi:10.1007/s11947-012-0867-9.

Pellegrini, M., Lucas-Gonzales, R., Ricci, A., Fontecha, J., Fernández-López, J., Pérez-Álvarez, J. A., \& Viuda-Martos, M. (2018). Chemical, fatty acid, polyphenolic profile, techno-functional and antioxidant properties of flours obtained from quinoa (Chenopodium quinoa Willd) seeds. Industrial Crops and Products, 111, 38-46. doi:10.1016/j.indcrop.2017.10.006.

Pereira, E., Encina-Zelada, C., Barros, L., Gonzales-Barron, U., Cadavez, V., \& Ferreira, I. C. F. R. (2019). Chemical and nutritional characterization of Chenopodium quinoa Willd. (quinoa) grains: A good alternative to nutritious food. Food Chemistry, 280, 110-114. doi:10.1016/j.foodchem.2018.12.068.

Quintana, G., Gerbino, E., \& Gómez-Zavaglia, A. (2017). Okara: A nutritionally valuable by-product able to stabilize Lactobacillus plantarum during freeze-drying, spray-drying, and storage. Frontiers in Microbiology, 8. doi:10.3389/fmicb.2017.00641. art. no. 641.
Quintana, G., Gerbino, E., \& Gómez-Zavaglia, A. (2018). Valorization of okara oil for the encapsulation of Lactobacillus plantarum. Food Research International, 106, 81-89. doi:10.1016/j.foodres.2017.12.053.

Quintana, G., Spínola, V., Martins, G. N., Gerbino, E., Gómez-Zavaglia, A., \& Castilho, P. C. (2019). Release of health-related compounds during in vitro gastro-intestinal digestion of okara and okara fermented with Lactobacillus plantarum. Journal of Food Science and Technology. doi:10.1007/s13197-019-04140-7.

Ratnayake, W. S., Otani, C., \& Jackson, D. S. (2009). DSC enthalpic transitions during starch gelatinisation in excess water, dilute sodium chloride and dilute sucrose solutions. Journal of the Science of Food and Agriculture, 89, 2156-2164. doi:10.1002/ jsfa.3709.

Re, R., Pellegrini, N., Proteggente, A., Pannala, A., Yang, M., \& Rice-Evans, C. (1999). Antioxidant activity applying an improved ABTS radical cation decolorization assay. Free Radical Biology and Medicine, 26, 1231-1237. doi:10.1016/S0891-5849(98)00315-3.

Rodríguez, S. D., Rolandelli, G., \& Buera, M. P. (2019). Detection of quinoa flour adulteration by means of FT-MIR spectroscopy combined with chemometric methods. Food Chemistry, 274, 392-401. doi:10.1016/j.foodchem.2018.08.140.

Romano, N., Mobili, P., Zuñiga-Hansen, M. E., \& Gómez-Zavaglia, A. (2018). Physico-chemical and structural properties of crystalline inulin explain the stability of Lactobacillus plantarum during spray-drying and storage. Food Research International, 113, 167-174. doi:10.1016/j.foodres.2018.07.007.

Santivarangkna, C., Higl, B., \& Foerst, P. (2008). Protection mechanisms of sugars during different stages of preparation process of dried lactic acid starter cultures. Food Microbiology, 25, 429-441. doi:10.1016/j.fm.2007.12.004.

Santos, M. I., Araujo-Andrade, C., Tymczyszyn, E. E., \& Gómez-Zavaglia, A. (2014). Determination of amorphous/rubbery states in freeze-dried prebiotic sugars using a combined approach of near-infrared spectroscopy and multivariate analysis. Food Research International, 64, 514-519. doi:10.1016/j.foodres.2014.07.040.

Sosa, N., Gerbino, E., Golowczyc, M. A., Schebor, C., Gómez-Zavaglia, A., \& Tymczyszyn, E. E. (2016). Effect of galacto-oligosaccharides: Maltodextrin matrices on the recovery of Lactobacillus plantarum after spray-drying. Frontiers in Microbiology, 7. doi:10.3389/fmicb.2016.00584. art. no. 584.

Srichuwong, S., \& Jane, J.-L. (2007). Physicochemical properties of starch affected by molecular composition and structures: A review. Food Science and Biotechnology, 16, 663-674.

Tontul, I., \& Topuz, A. (2017). Effects of different drying methods on the physicochemical properties of pomegranate leather (pestil). LWT - Food Science and Technology, 80, 294-303. doi:10.1016/j.lwt.2017.02.035.

Tontul, I., \& Topuz, A. (2017). Spray-drying of fruit and vegetable juices: Effect of drying conditions on the product yield and physical properties. Trends in Food Science \& Technology, 63, 91-102. doi:10.1016/j.tifs.2017.03.009.

Turkmen, N., Sari, F., \& Velioglu, Y. S. (2005). The effect of cooking methods on total phenolics and antioxidant activity of selected green vegetables. Food Chemistry, 93, 713-718. doi:10.1016/j.foodchem.2004.12.038.

Vera, A., Valenzuela, M. A., Yazdani-Pedram, M., Tapia, C., \& Abugoch, L. (2019). Conformational and physicochemical properties of quinoa proteins affected by different conditions of high-intensity ultrasound treatments. Ultrasonics Sonochemistry, 51, 186-196. doi:10.1016/j.ultsonch.2018.10.026

Vicente, J., Pinto, J., Menezes, J., \& Gaspar, F. (2013). Fundamental analysis of particle formation in spray drying. Powder Technology, 247, 1-7. doi:10.1016/ j.powtec.2013.06.038.

Warren, F. J., Perston, B. B., Royall, P. G., Butterworth, P. J., \& Ellis, P. R. (2013). Infrared spectroscopy with heated attenuated total internal reflectance enabling precise measurement of thermally induced transitions in complex biological polymers. Analytica Chemistry, 85, 3999-4006. doi:10.1021/ac303552s.

Warren, F. J., Gidley, M. J., \& Flanagan, B. M. (2016). Infrared spectroscopy as a too to characterise starch ordered structure-a joint FTIR-ATR, NMR, XRD and DSC study. Carbohydrate Polymers, 139, 35-42. doi:10.1016/j.carbpol.2015.11.066.

Xu, B., \& Chang, S. K. (2008). Total phenolics, phenolic acids, isoflavones, and an thocyanins and antioxidant properties of yellow and black soybeans as affected by thermal processing. Journal of Agricultural and Food Chemistry, 56, 7165-7175. doi:10.1021/jf8012234. 